\title{
Socio-Environmental Impact of Water Pollution on the Mid-Canal (Meda Ela), Sri Lanka
}

\author{
K. B. S. N. Jinadasa ${ }^{1}$, S. K. I. Wijewardena ${ }^{2}$, Dong Qing Zhang ${ }^{3^{*}}$, Richard M. Gersberg ${ }^{4}$, \\ C. S. Kalpage ${ }^{5}$, Soon Keat $\mathrm{Tan}^{3}$, Jing Yuan Wang ${ }^{3}$, Wun Jern $\mathrm{Ng}^{3}$ \\ ${ }^{1}$ Department of Civil Engineering, University of Peradeniya, Peradeniya, Sri Lanka \\ ${ }^{2}$ Works Department, Kandy Municipal Council, Kandy, Sri Lanka \\ ${ }^{3}$ Nanyang Environment \& Water Research Institute (NEWRI), Nanyang Technological University, Singapore City, Singapore \\ ${ }^{4}$ Graduate School of Public Health, San Diego State University, Hardy Tower Campanile, San Diego, USA \\ ${ }^{5}$ Department of Chemical and Process Engineering, University of Peradeniya, Peradeniya, Sri Lanka \\ Email: dqzhang@ntu.edu.sg
}

Received April 10, 2012; revised May 4, 2012; accepted May 31, 2012

\begin{abstract}
Unplanned urban population growth in developing countries such as Sri Lanka exert pressures on the sectors of water supply, sewage disposal, waste management, and surface drainage in the cities as well as their surrounding areas. The Mid-canal is considered the most polluted surface water body in the Kandy district of Sri Lanka and contributes significantly to pollution of the Mahaweli River. Health problems in the nearby population may well be associated with environmental degradation and related to deteriorated water quality. The overall objectives of this study were to identify the socio-economic status of the community settled along the Meda Ela banks, and to examine the current water quality status of the Meda Ela and possible impacts of the nearby residents on water quality. Additionally, we propose remedial measures concerning wastewater and solid waste disposal to improve environmental conditions in this area.
\end{abstract}

Keywords: Meda Ela; Sri Lanka; Environment; Pollution; Water Quality

\section{Introduction}

One of the most important demographic trends in the world today is urbanization, with particularly rapid growth in developing countries which is believed to be an important cause of the degradation of natural water resources. In future decades, almost the entire population growth in the world is likely to be in the urban population, primarily in Asia [1]. With rural-urban migration, it has been estimated that by the year 2025, approximately fifty percent of the population will live in the growing cities of less developed countries [2]. Unplanned urban population growth exerts pressures on water resources, and water pollution has emerged as one of the most critical environmental problems in Asia. Such growth has major impacts on water supply, sewage disposal, waste management, surface drainage, and can cause environment health problems.

Kandy is recognized as a world heritage city by the United Nations Educational, Scientific and Cultural Organization (UNESCO) on account of its long and venerable history and its many cultural treasures. A canal (called Mid-canal or "Meda Ela") originates from the overflow sluice of the Kandy Lake, runs through the den-

\footnotetext{
${ }^{*}$ Corresponding author.
}

sely populated city, and thereafter drains into the Mahaweli, which is the largest river basin in Sri Lanka, draining about $16 \%\left(10,327 \mathrm{~km}^{2}\right)$ of Sri Lanka's land surface. Urbanization and population growth in Kandy city has rapidly increased in the volumes of wastewater generated in the region to about $20,000 \mathrm{~m}^{3} \cdot \mathrm{day}^{-1}$ [3]. Since there is no proper wastewater disposal system, untreated domestic sewage is released directly into the Mid-canal [4].

In addition, Mid-canal receives wastewaters from small scale industries such as commercial laundries, textile dyeing operations, various workshops, a hospital, the city's main slaughterhouse, and miscellaneous dischargers such as petroleum and other oily waste from motor vehicle workshops. Furthermore, since the canal is topographically situated at a low elevation, a large number of side canals drain into the Mid-canal with their heavy pollutant loads. In addition, large water volumes from Kandy Lake spill over to the Mid-canal, especially during the rainy season. Therefore, polluted water in the Mid-canal is a potentially health hazard not only to the people living nearby, but also to persons the communities downstream.

Previous studies reported on some of the socioeconomic implications of water pollution in the Meda Ela catchment and found that the awareness on water 
pollution issues of the community that lived next to the Mid-canal was high, although "discharge of gray water as well as black water by people who live close to the canal was evident" [3]. However, to date, there has been no comprehensive socio-economic survey on the urban population living adjacent to the Mid-canal. The overall objectives of this study were to: 1) identify the socioeconomic status of the community settled along the Midcanal banks; 2) identify the current water quality status of the Mid-canal and possible impacts of the community on water quality; and 3) propose remedial measures concerning wastewater and solid waste disposal to improve environmental conditions in this area.

\section{Materials and Methods}

Figure 1 shows a map of the study area. Mid-canal begins from Kandy Lake (on the top right hand corner of Figure 1) and flows through the city with a $5 \mathrm{~km}$ stretch running parallel to the William Gopallawa road. The confluence with Mahaweli River is at Getembe (on the bottom left hand corner of Figure 1).

\subsection{Socio-Environmental Survey}

The target group for the socio-environmental survey were the residents living along the canal bank of the Mid-canal. Nearly 350 houses are located along the canal bank. A questionnaire survey was conducted in Oct of 2010 with the help of Mid-canal community organizations and postgraduates from University of Peradeniya, Sri Lanka, through interviews with the 67 households. In addition, 15 businesses, commercial and public establishments were surveyed to collect necessary data for the identification of major types of pollutants. The open area of Mid-canal was divided into 5 segments according to topography and population density. Three focused group discussions and key information interviews were conducted to collect socio-economic information. The data were

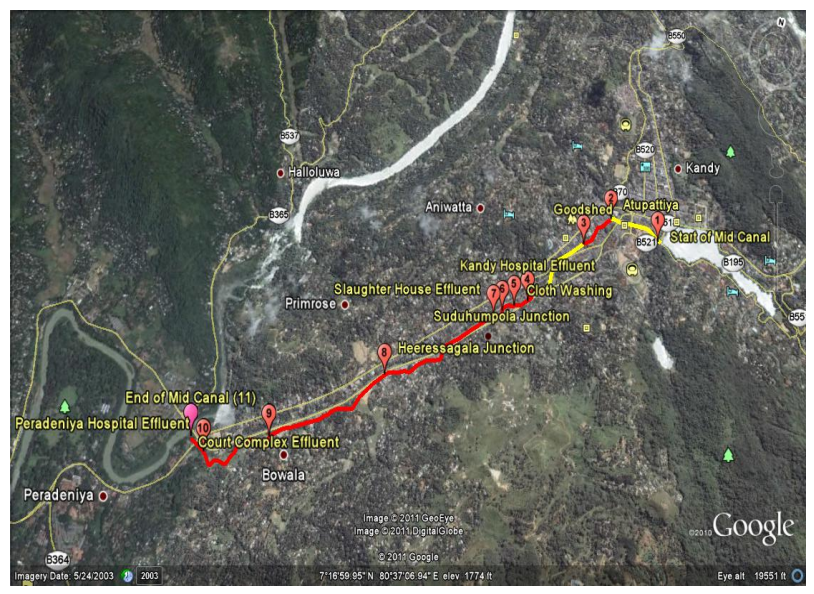

Figure 1. Route of the Mid-canal (Meda Ela). analyzed using MS Excel and SPSS statistical programmes.

\subsection{Maintaining the Integrity of the Specifications}

The template is used to format your paper and style the text. All margins, column widths, line spaces, and text fonts are prescribed; please do not alter them. You may note peculiarities. For example, the head margin in this template measures proportionately more than is customary. This measurement and others are deliberate, using specifications that anticipate your paper as one part of the entire journals, and not as an independent document. Please do not revise any of the current designations.

A water quality assessment was carried out at 11 locations along the Mid-canal to analyse 16 physical, chemical and biological parameters for both the wet and dry seasons. Additionally, the 11 selected locations included five wastewater point sources-Kandy hospital, Peradeniya hospital, Kandy new courts complex, Kandy suduhumpola slaughter house, and Kandy hospital private laundry. These were considered to encompass the significant point sources in this region. Sampling was conducted at approximately equal distances along the length of the canal. Table 1 shows 11 sampling locations along the Mid-canal.

Effluent samples were collected on the same day and at the same time, and were refrigerated $\left(4^{\circ} \mathrm{C}\right)$ and transported to the laboratory. Temperature, $\mathrm{pH}$, dissolved oxygen (DO) and electrical conductivity (EC) were measured using a Multi-Parameter Digital Meter (HACHHQ40d, USA) on site. Turbidity was measured using a ESD-800 Digital Nephlometric Turbidity Meter. Total suspended solids (TSS) were determined gravimetrically using Standard Methods [5]. In addition, the samples were immediately analyzed to determine the concentration of the parameters: $\mathrm{COD}, \mathrm{BOD}_{5}$, ammonia-N $\left(\mathrm{NH}_{4}^{+}-\right.$ $\mathrm{N})$, nitrate $\left(\mathrm{NO}_{3}^{-}-\mathrm{N}\right)$, and total phosphorus (TP). These conventional parameters were analyzed colorimetrically using a spectrophotometer (HACH-DR3800, USA) in accordance with standard methods [5]. Faecal coliform densities were determined by the membrane filtration technique [5] using a Millipore type HA $0.45 \mu \mathrm{m}$ pore size membrane filter and enumerated on M-FC medium. This test was carried out within 24 hours of sampling.

\section{Results and Discussion}

\subsection{Socio-Environmental Survey}

The survey indicated that urban population along the Mid-canal has steadily increased over the past few years and has produced a rapid increase in the volumes of wastewater generated. The total population of Kandy District was $1,279,028$ and the urbanisation rate is $2.5 \%$ 
Table 1. Sampling locations along the Mid-canal.

\begin{tabular}{clcc}
\hline & Location-Along Mid-canal & Point sources & $\begin{array}{c}\text { Distance from the Mid-canal } \\
\text { starting point }(\mathrm{km})\end{array}$ \\
\hline 1 & Outlet of the Kandy Lake & 0.00 \\
2 & Atupattiya (The point it reappears through a tunnel close to Mallika Studio) & & 0.50 \\
3 & Goods shed (The point it goes underground close to Goods shed Bus stand) & $\sqrt{ }$ & 0.80 \\
$4^{*}$ & Hospital treatment Plant effluent-I & $\sqrt{ }$ & 1.90 \\
$5^{*}$ & Wastewater from cloth washing tanks & $\sqrt{ }$ & 1.95 \\
6 & Upstream to Suduhumpola Junction & $\sqrt{ }$ & 2.00 \\
$7 *$ & Slaughter house effluent & $\sqrt{ }$ & 3.20 \\
8 & Downstream to Heeressagala Junction & & 3.25 \\
$9^{*}$ & Effluent of court complex & & 5.30 \\
$10^{*}$ & Hospital treatment plant effluent-II & & 5.30 \\
11 & End of Mid-canal & & \\
\hline
\end{tabular}

per annum [3]. Our survey showed that Sinhalese and Muslims comprise about $48 \%$ and $45 \%$, respectively of the population along the Meda Ela. The majority of people are at a medium income level for Sri Lanka and the Gross Domestic Product (GDP) per capita was estimated to be approximately US $\$ 2400$. The survey revealed that there is a direct relationship between income and the quantum of wastewater generated (i.e., increasing as income increases). The education level is relatively good and $94 \%$ of the respondents in the sample had taken for the Ordinary Level Examination. Results of a Spearman's correlation analysis showed that there is a significant correlation $(p<0.01)$ between education and legal awareness of waste disposal into water bodies.

Figure 2 shows the sources of drinking water and the types of bathing \& washing waters used along the Midcanal. Approximately $87 \%$ of people have pipes connected for potable water to their houses. However, some of residents still use unprotected wells on the canal bank for domestic purpose. Average family size was five and average consumption of water per family was 995 $\mathrm{L} \cdot \mathrm{day}^{-1}$. About $91 \%$ of the families surveyed used piped water for bathing and washing and only $4 \%$ of the people use common bathing places. However, survey results also showed quite clearly that residents did not use water from the Mid-canal for their drinking, bathing or washing purposes.

The survey also revealed that either most households along the Mid-canal dispose of their sewerage directly into the Mid-canal or else there is no well-maintained effective wastewater disposal mechanism. Figure 3 shows wastewater and municipal solid waste disposal. According to the survey, the average amount of wastewater generated by a family was approximately $798 \mathrm{~L} \cdot \mathrm{day}^{-1}$. Approximately $64 \%$ of generated wastewater is discharged directly into the Mid-canal, and a secondary method of wastewater disposal is soakage pits $(29 \%$ of generated wastewater) that are used to infiltrate septic tank effluent into the surrounding soil and enable surrounding soil to treat the effluent before entering the ground water table or water body. Wastewater from sources such as open drainage channels, pipe lines, and covered drains were also discharged to the Mid-canal. The survey also indicated that a majority $(91 \%)$ of the households surveyed had toilet facilities and $9 \%$ used common toilets. The Japanese International Cooperation Agency (JICA) estimated that approximately $1000 \mathrm{~m}^{3} \cdot$ day $^{-1}$ of sewerage or blackwater flows into Meda Ela [6].

With respect to municipal solid waste disposal, nearly 100 tonnes day $^{-1}$ of solid waste is generated within Kandy city [7] and average household solid waste generation was $1.5 \mathrm{~kg} \cdot \mathrm{day}^{-1}$ [3]. The previous study also concluded that waste generation pattern could be related to the income levels and consumption patterns of the people [3]. Our survey indicated that $71 \%$ of the Mid-canal community disposed of their waste in municipal waste bins or collecting carts, but $29 \%$ of them disposed of their waste into the Mid-canal (Figure 3). The survey also revealed that even some people who reside outside the Meda Ela catchment also dispose of solid waste into the canal. In contrast, the residents who live near the canal oppose dumping the solid waste into the canal since these wastes block the water course and create problems for them.

\subsection{Water Quality Assessment along the Mid-Canal}

Overall, results of the water quality assessment showed an obvious increase in the water quality deterioration towards the end of the Mid-canal (Tables 2-5). The water quality analysis indicated the pollution level during the wet season was high. The increased levels of several parameters (e.g., colour, turbidity, $\mathrm{BOD}_{5}, \mathrm{COD}, \mathrm{NH}_{4}^{+}-$ 

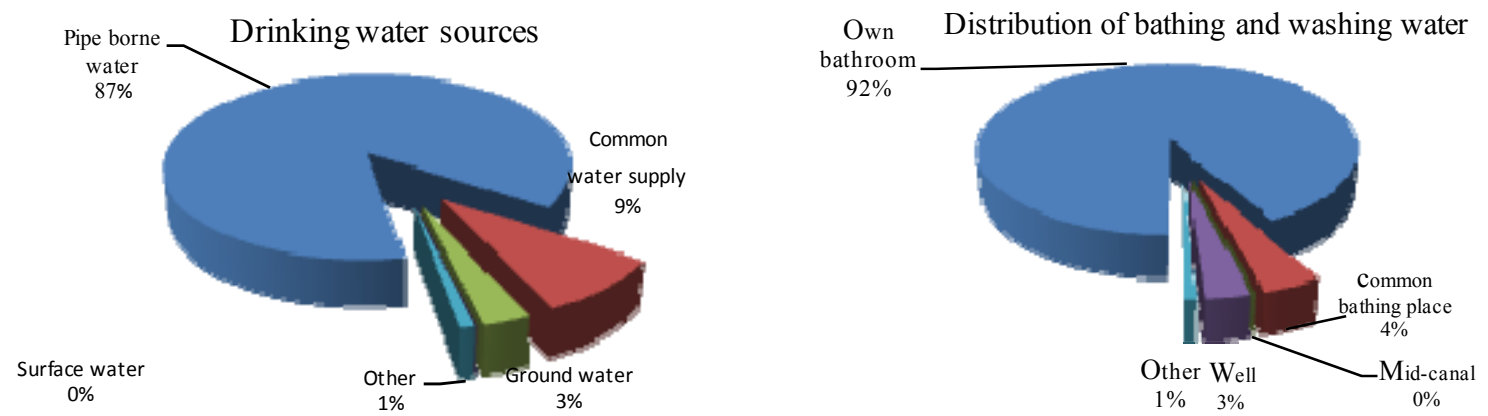

Figure 2. Drinking water sources and distribution of bathing and washing water.

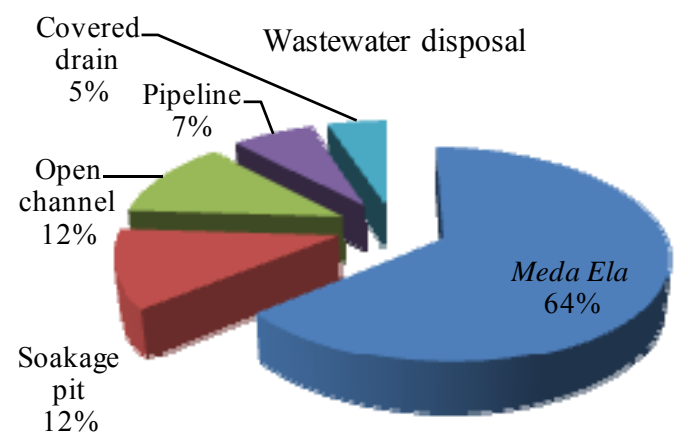

Solid waste disposal

Figure 3. Wastewater and municipal solid waste disposal.

Table 2. Water quality variation along the canal (physical parameter).

\begin{tabular}{|c|c|c|c|c|c|c|c|c|c|c|c|c|}
\hline \multicolumn{2}{|c|}{ Location } & 1 & 2 & 3 & 4 & 5 & 6 & 7 & 8 & 9 & 10 & 11 \\
\hline \multirow{2}{*}{$\begin{array}{c}\mathrm{EC} \\
\left(\mu \mathrm{S} \cdot \mathrm{cm}^{-1}\right)\end{array}$} & Wet & 240 & 328 & 316 & 572 & 350 & 325 & 200 & 234 & 380 & 367 & 300 \\
\hline & Dry & 276 & 378 & 370 & 691 & 604 & 429 & - & 330 & 579 & 320 & 317 \\
\hline $\begin{array}{l}\text { Colour } \\
\text { (PtCo) }\end{array}$ & Dry & 75 & 69 & 95 & 375 & 1655 & 85 & - & 41 & 40 & 42 & 92 \\
\hline $\begin{array}{l}\text { Turbidity } \\
\text { (NTU) }\end{array}$ & Wet & 4.3 & 10.1 & 12.7 & 16.2 & 97.6 & 16.5 & 892 & 37.5 & 4.3 & 40.2 & 55 \\
\hline \multirow{2}{*}{$\begin{array}{c}\mathrm{TSS} \\
\left(\mathrm{mg} \cdot \mathrm{L}^{-1}\right)\end{array}$} & Wet & 48 & 108 & 40 & 36 & 122 & 91 & 3073 & 122 & 91 & 584 & 273 \\
\hline & Dry & 94 & 106 & 123 & 198 & 532 & 148 & - & 49 & 27 & 32 & 145 \\
\hline
\end{tabular}

Table 3. Water quality variation along the canal (organic matter).

\begin{tabular}{ccccccccccccc}
\hline \multicolumn{2}{c}{ Location } & 1 & 2 & 3 & 4 & 5 & 6 & 7 & 8 & 9 & 10 & 11 \\
\hline $\begin{array}{c}\mathrm{DO} \\
\left(\mathrm{mg} \cdot \mathrm{L}^{-1}\right)\end{array}$ & Wet & 5.14 & 4.24 & 3.47 & 1.18 & 3.80 & 3.50 & 3.43 & 3.68 & 4.49 & 5.05 & 2.00 \\
$\mathrm{BOD}$ & Dry & 5.34 & 3.67 & 3.89 & 2.29 & 3.81 & 1.37 & - & 4.24 & 3.97 & 2.7 & 3.15 \\
$\left(\mathrm{mg} \cdot \mathrm{L}^{-1}\right)$ & Wet & 4.83 & 15.5 & 3.96 & 62 & 430 & 8.7 & 2646 & 37 & 4.26 & 407 & 111 \\
$\mathrm{COD}$ & Dry & 1.5 & 27 & 44 & 70.5 & 520 & 29 & - & 23 & 27 & 88 & 44 \\
$\left(\mathrm{mg} \cdot \mathrm{L}^{-1}\right)$ & Wet & 5 & 17 & 4 & 88 & 600 & 10 & 2766 & 46 & 8 & 610 & 153 \\
\hline
\end{tabular}

Table 4. Water quality variation along the canal (coliforms: count $100 \mathrm{~mL}^{-1}$ ).

\begin{tabular}{|c|c|c|c|c|c|c|c|c|c|c|c|c|}
\hline \multicolumn{2}{|c|}{ Location } & 1 & 2 & 3 & 4 & 5 & 6 & 7 & 8 & 9 & 10 & 11 \\
\hline \multirow{2}{*}{$\begin{array}{l}\text { Total } \\
\text { coliform }\end{array}$} & Wet & 144 & 300 & 300 & 6500 & 1000 & 400 & 3600 & 300 & 40 & 300 & 500 \\
\hline & Dry & 200 & 400 & 300 & 4200 & 800 & 500 & - & 300 & 200 & 5800 & 800 \\
\hline \multirow{2}{*}{$\begin{array}{l}\text { Faecal } \\
\text { coliform }\end{array}$} & Wet & 58 & 100 & 100 & 5400 & 200 & 200 & 2500 & 100 & 0 & 200 & 200 \\
\hline & Dry & 100 & 200 & 200 & 3400 & 200 & 300 & - & 100 & 0 & 4700 & 400 \\
\hline
\end{tabular}


Table 5. Water quality variation along the canal (nitrogen and phosphorus).

\begin{tabular}{|c|c|c|c|c|c|c|c|c|c|c|c|c|}
\hline \multicolumn{2}{|c|}{ Location } & \multirow{2}{*}{$\begin{array}{c}1 \\
1.8\end{array}$} & \multirow{2}{*}{$\begin{array}{l}2 \\
1\end{array}$} & \multirow{2}{*}{$\begin{array}{c}3 \\
1.4\end{array}$} & \multirow{2}{*}{$\begin{array}{c}4 \\
0.5\end{array}$} & \multirow{2}{*}{$\begin{array}{c}5 \\
0.7\end{array}$} & \multirow{2}{*}{$\begin{array}{c}6 \\
1.9\end{array}$} & \multirow{2}{*}{$\begin{array}{c}7 \\
3.6\end{array}$} & \multirow{2}{*}{$\begin{array}{c}8 \\
1.8\end{array}$} & \multirow{2}{*}{$\begin{array}{c}9 \\
4.3\end{array}$} & \multirow{2}{*}{$\begin{array}{l}10 \\
43\end{array}$} & \multirow{2}{*}{$\frac{11}{27.7}$} \\
\hline $\mathrm{NO}_{3}^{-}$ & Wet & & & & & & & & & & & \\
\hline$\left(\mathrm{mg} \cdot \mathrm{L}^{-1}\right)$ & Dry & 2.5 & 1.6 & 0.7 & 28.7 & 1.6 & 0.6 & - & 1.5 & 2.8 & 17 & 14 \\
\hline \multirow{2}{*}{$\begin{array}{c}\mathrm{NH}_{4}^{+} \\
\left(\mathrm{mg} \cdot \mathrm{L}^{-1}\right)\end{array}$} & Wet & 3.9 & 2.6 & 4.7 & 5.1 & 2.3 & 5.2 & 7.1 & 5.4 & 4.7 & 47.3 & 39.6 \\
\hline & Dry & 3.9 & 2.8 & 6.4 & 26 & 2.6 & 5.9 & - & 8.7 & 3.1 & 19.4 & 16.9 \\
\hline \multirow{2}{*}{$\begin{array}{c}\mathrm{PO}_{4}^{3-} \\
\left(\mathrm{mg} \cdot \mathrm{L}^{-1}\right)\end{array}$} & Wet & 0.4 & 0.3 & 0.7 & 3.2 & 0.6 & 0.9 & 4.1 & 1.7 & 0.4 & 9 & 5.1 \\
\hline & Dry & 0.5 & 0.2 & 0.5 & 7.5 & 0.4 & 2.1 & - & 1.9 & 0.4 & 7 & 3.4 \\
\hline \multirow{2}{*}{$\begin{array}{c}\mathrm{TP} \\
\left(\mathrm{mg} \cdot \mathrm{L}^{-1}\right)\end{array}$} & Wet & 0.2 & 0.1 & 0.3 & 2.5 & 0.3 & 0.4 & 3.6 & 0.6 & 0.1 & 7.1 & 2.9 \\
\hline & Dry & 0.2 & 0.1 & 0.2 & 2.5 & 0.1 & 0.6 & - & 0.6 & 0.1 & 4.9 & 1.1 \\
\hline
\end{tabular}

$\mathrm{N}$ and phosphorus) in downstream segments of the Midcanal indicated the likelihood of deteriorating water quality in wet weather (Figure 4).

In this study, the $\mathrm{pH}$ values varied in the range 6.6 7.2 and water temperature was around $25^{\circ} \mathrm{C}-26^{\circ} \mathrm{C}$ during the study period (not presented in the table). For electrical conductivity (EC), the highest EC value (430 $\mu \mathrm{S} \cdot \mathrm{cm}^{-1}$ ) along the canal was at Suduhumpola junction (Figure 4(a)) in the dry season. The EC would likely have originated from the upstream Kandy Hospital because of laundry effluents which comprise of high load of sodium ion [8]. Table 2 shows the level of colour wet up markedly in wet weather. One of the main reasons for higher level of colour during rain could be that some factories or cottage industries discharge their waste into the Mid-canal during rainy days. As for turbidity (as well as colour), both parameters increased at the downstream end of the canal also during the wet season. All the sample points showed the turbidity above the standard during the wet season (Figure 4(c)) and most of the sample points exceed the Ambient Water Quality Standards for Inland Waters in Sri Lanka: 50 NTU (Table 2).

Dissolved oxygen (DO) was low at the end of the canal, especially in the wet season (Figure 4(e)). Previous studies had reported the DO concentration was 5.78 and $2.68 \mathrm{mg} \cdot \mathrm{L}^{-1}$ at the lake-outlet and end of the canal, respectively [9]. That study also reported DO values were 6.03 and $5.40 \mathrm{mg} \cdot \mathrm{L}^{-1}$ at $50 \mathrm{~m}$ upstream and $50 \mathrm{~m}$ downstream of the confluence with the Mid-canal. In the present study, DO levels were $3.15 \mathrm{mg} \cdot \mathrm{L}^{-1}$ in dry season and $2.00 \mathrm{mg} \cdot \mathrm{L}^{-1}$ in wet season just before the confluence of the Mahaweli River.

$\mathrm{BOD}_{5}$ and COD concentrations increased towards the end of the Mid-canal (Figures 4(f) and 4(g)) and the change was larger at the last few hundred metres before the confluence of the Mahaweli River. The $\mathrm{BOD}_{5}$ and COD values were 111 and $153 \mathrm{mg} \cdot \mathrm{L}^{-1}$ in the wet season at the end of the canal (Table 3), which are 3 - 5 fold higher than the effluent $\mathrm{BOD}_{5}$ discharge limit $\left(30 \mathrm{mg} \cdot \mathrm{L}^{-1}\right)$ in Sri Lanka. The main sources are the Kandy and Pera- deniya hospitals, along with the toilet discharges from the Mid-canal residences. Other substantial $\mathrm{BOD}_{5}$ and COD sources are the slaughter house and hospital laundry. An earlier water quality analysis programme had been conducted in March 2001 under the Greater Kandy Water Supply Augmentation Project showed $\mathrm{BOD}_{5}$ to be from 0.7 to $7.6 \mathrm{mg} \cdot \mathrm{L}^{-1}$ at $500 \mathrm{~m}$ downstream of the confluence of the Mid-canal with the Mahaweli River [6]. A subsequent study was conducted via the Kandy City Wastewater Management Project [10] and a higher $\mathrm{BOD}_{5}$ ranging from 2.13 to $10.5 \mathrm{mg} \cdot \mathrm{L}^{-1}$ was noted. Compared to previous investigation, the concentration of $\mathrm{BOD}_{5}$ that we measured of $111 \mathrm{mg} \cdot \mathrm{L}^{-1}$ suggests a progressively deteriorating water quality along the Mid-canal since 2005.

In the present study, the faecal and total coliform levels varied from 58 and $144 \mathrm{MPN}$ per $100 \mathrm{~mL}$ to 400 and 800 MPN per $100 \mathrm{~mL}$, respectively in dry and wet weather (Table 4). The total coliform values near the hospital discharge point were very high, at 5800 and 4200 per 100 $\mathrm{ml}$ for wet and dry weather respectively (Figures 4(l) and $\mathbf{4 ( m ) ) \text { . }}$

$\left(\mathrm{NH}_{4}^{+}-\mathrm{N}\right)$ concentrations were also relatively high in the wet season (Figure 4(j)). No fish were observed in the canal. $\mathrm{NH}_{4}^{+}-\mathrm{N}$ levels were extremely elevated at downstream site 11 showing levels of $16.9 \mathrm{mg} \cdot \mathrm{L}^{-1}$ during dry weather and $39.6 \mathrm{mg} \cdot \mathrm{L}^{-1}$ during wet weather. Table 5 also presents nitrate $\left(\mathrm{NO}_{3}^{-}-\mathrm{N}\right)$ concentrations in the Midcanal, which can be largely attributed to biogenic waste such as human and animal excreta as well as subsequent nitrification. Nitrification will occur at dissolved oxygen levels as low as $0.3 \mathrm{mg} \cdot \mathrm{L}^{-1}$ [11], and since it exerts an oxygen demand and can potentially result in some of the oxygen depletion that we observed.

Phosphorus is commonly the limiting factor in freshwater bodies in Sri Lanka [6]. The concentrations of total phosphorus and dissolved phosphate were high especially towards the end of the canal (Table 5). This suggested substantial contamination from human, animal excreta and organic waste discharged not only into the canal but also into Kandy Lake. Phytoplankton in Kandy 

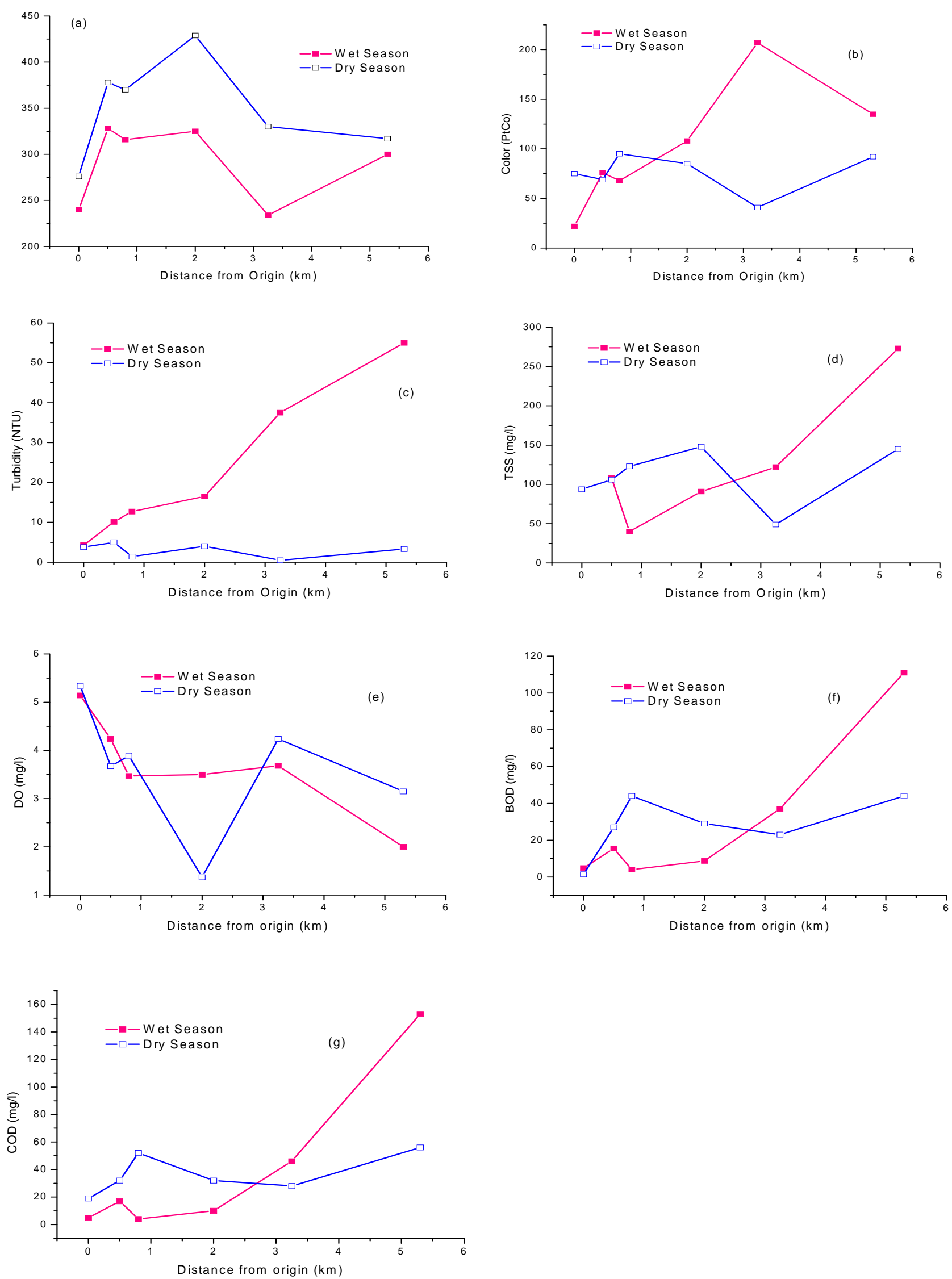

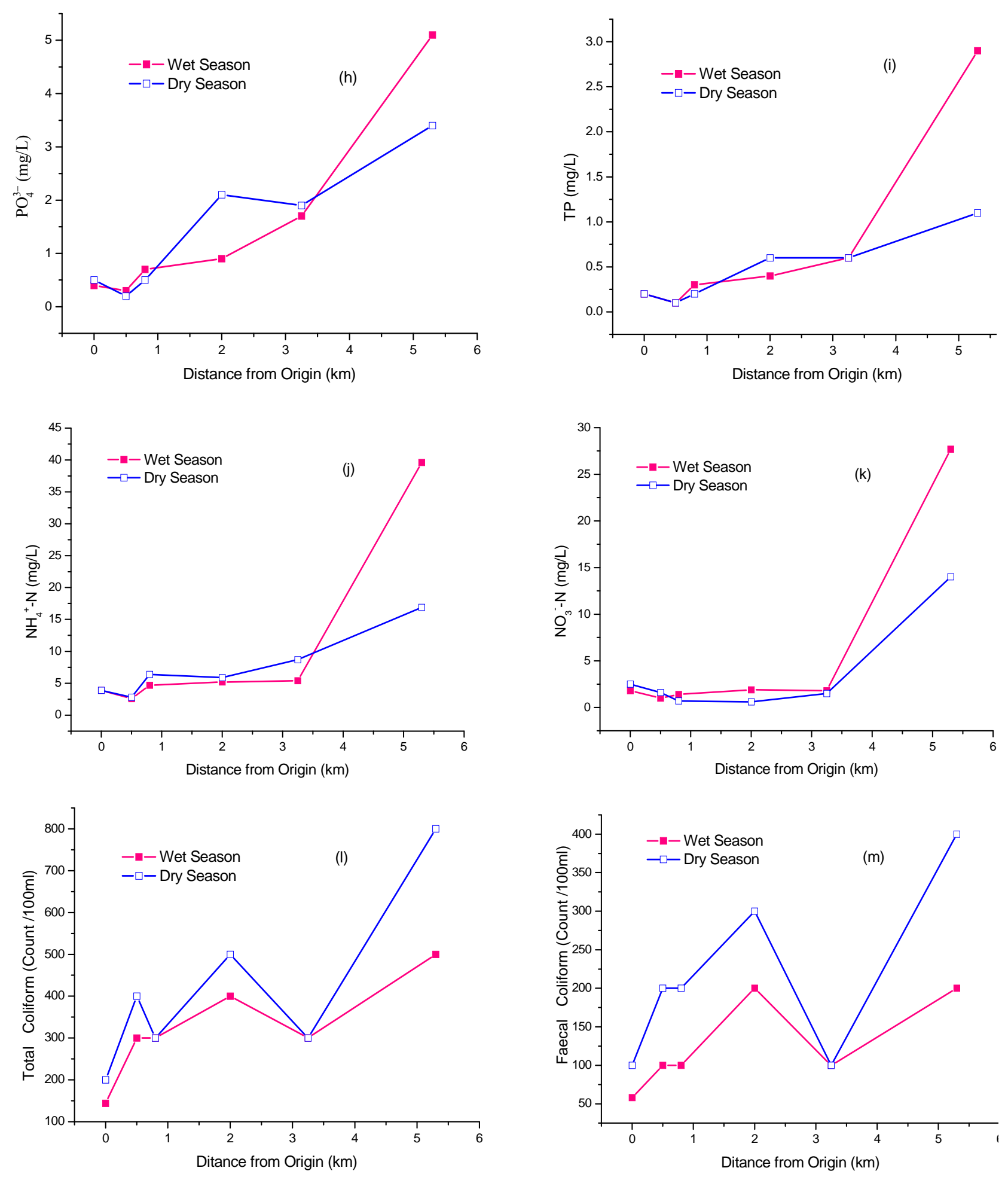

Figure 4. Water quality variations along the Mid-canal.

Lake, an urban and manmade water body, was examined for two consecutive years to determine species abundance and composition, and the lake was categorized as eutrophic due to nutrient discharge [12].

Access to safe drinking water and sanitation is recog- nized as a human right [13] and provision of clean water and safe disposal of wastewater should remain a basic necessity for daily survival and for all economic activities. Access to adequate sanitation and sewerage systems in the Kandy urban area, as well as access to appropriate 
on-site sanitation facilities for those not connected to a sewerage system, is a long-term strategy for the Kandy Municipal Council. In order to address this strategy, there is a need to develop wastewater treatment facilities for Kandy city and the Mid-canal catchment. JICA has funded the Kandy City Wastewater Management Project (KCWMP), which covers the Mid-canal catchment in their centralised wastewater treatment project and it shall be commissioned by 2016. This project is aimed at reducing the current adverse impact on the Mid-canal catchment due to wastewater discharges. The technological appropriateness, economic viability, social acceptance, political feasibility and the overall sustainability of the project shall be subject to scrutiny in the future.

There is no doubt that with the continuing urban sprawl along Mid-canal, the provision of adequate levels of drinking water and safe disposal of wastewater shall become increasingly complex and expensive. This then is an increasing challenge in coming years and implies that large financial investments will be required for the water sector in this area. As a matter of fact, centralized wastewater management is a very costly part of infrastructure and its elaborate systems of pipes, pumps and treatment plants, as well as its institutional and managerial requirements are unaffordable in many of developing countries [14]. Decentralized wastewater treatment is not a new technology and was in the past decades prevailing in rural areas worldwide. Nowadays the concept of decentralized wastewater management is far beyond traditional thinking and solution. It focuses not only on community-based wastewater collection, treatment, disposal, but also on rainwater harvesting, groundwater protection and surface water conservation. Raw material flow, energy generation and resource management can also be integrated into new decentralized water approach. Decentralized technological alternatives like (a combination of appropriately constructed) individual septic tanks integrated with constructed wetlands at the mini/micro watershed level and managed by community-based institutions [15] may be a viable alternative in the Kandy city area.

\section{Conclusions}

Urban water bodies are susceptible to high anthropogenic pressures and water quality conditions attributes are influenced by hygienic and economic conditions of the riparian communities. Management of these water bodies have been largely neglected in developing countries due possibly to inadequate environmental awareness and financial constrains. Mid-canal is a typical example of such a water body. Flowing through a densely populated area in the second largest city in Sri Lanka, it receives a variety of untreated effluents from point and non point sources. Urban water bodies like the Mid-canal have lost their aesthetic value and have instead gradually become seen by the community as a nuisance and health hazard.

This water quality analysis along Mid-canal indicated the pollution level in the wet season was high. Dissolved oxygen was low at the end of the canal and especially so in wet season. Total suspended solids values had exceeded the discharge limits at all locations along the canal. The concentration of $\mathrm{BOD}_{5}$ and COD increased towards the end of the Mid-canal, and the highest $\mathrm{BOD}_{5}$ values were much higher than the effluent $\mathrm{BOD}_{5}$ dis charge limit in Sri Lanka. Ammonia concentrations were above the inhibitory limit for fish and no fish were observed in the canal. Total phosphorus and phosphate concentrations were high towards the end of the canal. The results highlighted the need to generate awareness on protecting the environment and developing proper practices of wastewater and solid waste disposal to reduce nutrient levels in the canal water. Promoting waste reduction, reuse, recycling and final disposal in an environmentally sound manner are recommended from this study. Decentralized technological alternatives may be a vital, sustainable and cost-effective alternative. In addition to wastewater treatment and sanitation, systematic approaches and integrated remedial measures within the urban development sector have to be taken to develop a sustainable socio-environmental improvement plan to mitigate pollution in the Mid-canal of Sri Lanka.

\section{REFERENCES}

[1] M. Keiner, "Towards Gigapolis? From Urban Growth to Evolutionable Medium-Sized Cities,” In: M. Keiner, M. Koll-Schretzenmayr and W. Schmid, Eds., Managing Urban Futures, Ashgate Publishing Limited, England, 2006.

[2] P. Jayakody, L. Raschid-Sally, S. A. K. Abeywardana and M. Najim, "Sustainable Development of Water Resources, Water Supply and Environment Sanitation," 32nd WEDC International Conference, Colombo, 2006.

[3] A. W. G. N. Abeygunawardane, N. D. K. Dayawansa and S. Pathmarajha, "Socioeconomic Implications of Water Pollution in an Urban Environment: A Case Study in Meda Ela Catchment, Kandy, Sri Lanka," Tropical Agricultural Research, Vol. 22, No. 4, 2011, pp. 374-383.

[4] A. M. C. P. K. Abeysinghe, "Willingness to Pay for Wastewater Disposal by Commercial Water Users in Kandy Municipality," Unpublished Final Year Project Report, University of Peradeniya, ECON/07/02, Sri Lanka, 2007.

[5] APHA, "Standard Methods for the Examination of Water and Wastewater," American Public Health Association, 1989.

[6] JICA, "Greater Kandy Water Supply Augmentation Project, Final Report, Volume II-I, Main Report (I),” Project Report, Japan International Co-Operation Agency, 2002.

[7] Urban Development Authority, "Development Plan for 
Urban Development Area of Kandy," Situation Report, Sri Lanka, 2001.

[8] R. A. Patterson, "Demonstration of Effects of Sodicity on Soil Hydraulic Conductivity," Proceedings of the Innovative Approaches to the On-Site Management of Waste and Water, Southern Cross University, Australia, 26 November 1996.

[9] P. D. W. S. Poddalgoda, "The Status of the Effluent Discharge into Meda-Ela and Its Impact on the Mahaweli River," M.Sc. Thesis, University of Peradeniya, Sri Lanka, 1996.

[10] JICA, "Kandy City Wastewater Management Project," Project Report, Japan International Co-Operation Agency, 2005.

[11] D. R. Keeney, "The Nitrogen Cycle in Sediment-Water System," Journal of Environmental Quality, Vol. 2, 1973, pp. $15-29$. doi:10.2134/jeq1973.00472425000200010002x

[12] E. I. L. Silva, "Water Quality of Sri Lanka: A Review on Twelve Water Bodies, Kandy," Department of Environmental Sciences, Institute of Fundamental Studies, 1996.

[13] United Nations, "Human Rights and Access to Safe Drinking Water and Sanitation," The Human Rights Council, A/HRC/15/L.14, 2010.

[14] U. Winblad, "First International Conference on Ecological Sanitation," Official Conference Report, Naning, 5-8 November 2001.

[15] N. C. Narayanan and S. Thrikawala, "Aid, Technology and Project Dependence: A Case of Institutional Weakening of Water Sector from Sri Lanka," Journal of South Asian Water Studies, Vol. 2, No. 2, 2010, pp. 59-74. 